\title{
How Do We Gather Knowledge Through Language? ${ }^{1}$
}

\section{ELISA FRESCHI}

Austrian Academy of Sciences and University of Vienna (elisa.freschi@oeaw.ac.at)

\author{
MaLCOLM KEATING \\ Yale-NUS College (malcolm.keating@yale-nus.edu.sg)
}

The present issue of Journal of World Philosophies will host a series of papers discussing the phenomenon of linguistic communication ${ }^{2}$ from a philosophical point of view and from a cross-cultural perspective. ${ }^{3}$ The papers' authors discussed the topic together with some other scholars in a workshop in Athens, 2015.4

European philosophy has long been suspicious of the epistemic status of propositions conveyed linguistically. The 1660 motto of the Royal Society, Nullius in Verba ("on no one's word [shall I put trust]"), is in this sense the ensign of this position, echoed in John Locke's complaint that "The floating of other men's opinions in our brains makes us not one jot the more knowledge, though they happen to be true." ${ }^{5}$ However, nearly everyone (even Locke elsewhere) agrees that linguistic communication sometimes results in knowledge. Two questions then immediately arise: under what conditions can we characterize the resultant beliefs as "knowledge," and in virtue of what-the act of communication itself or something else? However, while assertoric language has long been the dominant paradigm for epistemological analysis, linguistic phenomena are varied, ranging in their form and content. We might wonder whether privileging assertion over, say, injunction or implication, is warranted. Moreover, human language is embedded within cultures. We might ask what influence its situatedness has on knowing.

The present series of contributions will deal with these topics from different points of view, elaborating on materials from the classical Indian, ancient Greek, and medieval Arabic traditions. We hope to contribute to a debate whose foundations have been set by works such as Matilal and Chakrabarti's Knowing from Words, ${ }^{6}$ which focused on the topic of testimony from the perspective of Indian Philosophy (especially Nyāya) and of analytic philosophy. ${ }^{7}$

The contributions are organized around the following four issues:

1. What do we know?

2. How (through which instrument of knowledge) do we know it?

3. What is the role of language as a medium?

4. What is the role of the social context?

Journal of World Philosophies 2 (Summer 2017): 42-46

Copyright ( 2017 Elisa Freschi and Malcolm Keating.

e-ISSN: 2474-1795 • http://scholarworks.iu.edu/iupjournals/index.php/jwp• doi: 10.2979/jourworlphil.2.1.04 


\section{What Do We Know?}

As for the first question, one might attempt a first distinction among utterances communicating states of affairs (descriptive contents), commands (prescriptive contents) and utterances conveying what, arguably, is neither a state of affairs nor a command. The last occurs in the following instance, in the parallel of one's beloved with the moon:

In the heaven the moon, on earth thy face..$^{8}$

Similar examples do not literally convey a state of affairs (the beloved's face is not really like the moon), nor do they order anything. And yet they do seem to convey something beyond the literal meaning (which may even be literally false, as in the present case); in the present example, the words convey one's admiration for one's beloved's looks. For lack of a better term, we decided to tentatively call this kind of content "affective content." This term works in our terminology for all sorts of contents others may call "poetical," in which the primary goal is to convey something directly relevant to the utterer or the listener and in a strongly connoted way. An objector may argue that affective contents are nothing but a subgroup of the previous two, or vice-versa. The status of affective contents has been discussed by Cuneo in the workshop mentioned in fn. 4 (see Daniele Cuneo, "Affective Knowledge as the Aim of Poetic Language" forthcoming). Further insights on the relation between metaphors and the act of communicating knowledge are also discussed within this volume in Keating's contribution.

These distinctions do not exhaust all instances of linguistically conveyed cognitions. There might be residual cases which escape this classification, and there are surely mixed ones. For instance, someone's asserting a particular state of affairs ("It is eight o'clock") may in fact aim at conveying a command ("Hurry up!"). Nonetheless, we believe that these basic distinctions should be kept in mind. Instances of linguistic communication in which the one or another aspect prevails may need different treatments (as will be discussed more in details in the contributions by Freschi et al. and by Keating).

\section{How (Through Which Instrument of Knowledge) Do We Know It?}

Classical Indian philosophers tend to think of linguistic communication as occurring either in dependence on a speaker (as with most European theories of testimony) or independent of a speaker, via the linguistic expression itself (in a way which might evoke Heidegger's emphasis on the primacy of language over its speakers). The Mīmāmsā school of classical Indian philosophy adopts the latter view in order to account for the epistemic reliability of the Vedas, whose validity does not depend on a (divine or human) author. However, the question of whether linguistic communication is a sui generis source of knowledge or reducible to another, such as inference (a dispute found also in European philosophy), cuts across these distinctions. The Nyāya school sees the validity of an act of communication as depending on the speaker, but agrees with the Mīmāmsā that linguistic communication is a sui generis instrument of knowledge, rejecting inferentialist accounts such as those in Buddhism, where we know that $p$ from a speaker's saying " $p$ " only through inference based on her being an expert, ordinarily truthful, etc.

The distinction among contents has an immediate impact on the second question, insofar as the requisites of the speaker and of the listener are differently conceived in the case of the three sorts of

Journal of World Philosophies 2 (Summer 2017): 42-46

Copyright (C) 2017 Elisa Freschi and Malcolm Keating.

e-ISSN: 2474-1795 • http://scholarworks.iu.edu/iupjournals/index.php/jwp• doi: 10.2979/jourworlphil.2.1.04 
contents. In the case of descriptive contents, a listener comes to know that $p$ through a linguistic expression provided that some basic requirements are fulfilled. Classical Indian and European philosophers disagree among themselves as to what they are, but they usually discuss: the competence of the speaker (highlighted in India in the Nyāya and in other Pramānavāda traditions), the competence of the listener, and the way of communication (direct statement, implication...). These basic requirements can be listed as:

- Truthfulness (of the speaker)

- Competence (of the speaker)

- Ability to trust (of the listener)

- Desire to communicate (of the speaker) ${ }^{10}$

- Truth (of the content)

But what do "competence" and "truthfulness" in the various cases exactly entail? And what do they entail in the case of prescriptive and affective contents? Within this series, Freschi et al. will focus on the anti-reductionist approach of the Mīmāmsā school of Indian philosophy and will elaborate in particular on the Mīmāmsāa account of descriptive and prescriptive contents. Keating will deal with the partly neglected hypothesis of a parallel between linguistic communication and what classical Indian philosophers call arthäpatti, an instrument of knowledge he argues is involved in metaphor and metonymy.

\section{What Is the Role of Language As a Medium?}

In many cases of linguistic communication, we just use language as if it were a transparent medium. In some cases, however, one becomes aware, typically by misunderstandings, of the presence of language and of its role in each instance of communication. Accordingly, any investigation on the role of language as a medium needs to focus on some liminal cases in which the illusion of the transparency of language is interrupted and the materiality of language becomes apparent. Thus, even more than in the preceding cases, we are aware that one could approach this topic from many perspectives. The following lines will explore the particular ways in which this has been attempted within this series.

Melis and Pontillo's joint contribution deals with the nature of the word-object relation. More precisely, the authors compare ancient Indian and Pre-Socratic Greek approaches to dissymmetries in the relation between the word-forms and the object they denote. Synonyms, homonyms and zeromorphs, in fact, violate the one-to-one word-object relation, substituting it with, respectively, many-toone, one-to-many, and null-to-one relationship. Hence, dissymmetries undermine the possibility of language's directly reflecting reality and, indirectly, they risk undermining the possibility of its being a reliable means of knowledge.

Saito's contribution deals with classical Indian answers to the problem of how audible speech is changed into its conceptual form and of which of the two steps is the carrier of meaning. Again, as long as one does not reflect on the material aspect of language, the intermediate step of internalized language will not even be detected. But some Indian philosophers of the Grammatical school (especially Bhartrhari and Mandana, 5th and 7th c. CE respectively) have pushed their analysis beyond audible speech, arguing 
that its existence necessarily presupposes an internalized and unuttered language, which in turn may even hint at the existence of an unarticulated internal speech—which would be tantamount to thought.

\section{What Is the Role of the Social Context?}

Even more so than in the preceding section, we must start by stating that the impact of the social context in the case of linguistic communication could be investigated from very different angles and perspectives and that the socio-epistemology of language as an instrument of knowledge is a promising, and possibly underdeveloped field. One way the social context enters the arena of linguistic communication is storytelling. Storytelling does not just frame the act of linguistic communication but alters the communicated meaning. It also adds shades of meaning so that the listener's belief or lack thereof in the content presented intrinsically depends on the story in which it is embedded (think of the Cretan paradox as the utterance of a repented liar and it is no longer a paradox). Storytelling can even have a transformative value, insofar as it changes the listener (and perhaps through her also the speaker). Thus, the ideal situation of a listener, a speaker, and a content is possibly much more muddled in actual reality; and the three can be reciprocally linked. Accordingly, the investigation of the hermeneutic circle linking speaker and listener(s) does not need to lie outside the precinct of philosophy (although it has often lain outside analytic philosophy), as shown by Ancient Greek (Plato, Aristotle's attention to poetical structures) and Arabic philosophy (see the treatment of Ibn Tufayl in Marco Lauri, "The Gadfly and the Rhapsode. Storytelling, knowledge and social agency through Greco-Arabic philosophy” forthcoming), as well as by the work of philosophers such as Richard Rorty, Paul Ricoeur and H.-G. Gadamer and by the usage of poetry and storytelling in the works of well-known philosophers such as Derrida, Nietzsche and, in Classical India, Veńkațanātha or Utpaladeva.

As a general, concluding note, let us underline our hope that these articles will contribute further to the cross-cultural philosophical dialogue on the topic of linguistic communication. We hope to have shown how this dialogue cannot be interrupted at Königsberg, since similar topics and methodology stretched from ancient Greece to ancient India via the Arab world. It is further our hope that this collection of essays will increase the awareness of the unavoidable role of language within the epistemological process, no matter where its actors are situated.

Elisa Freschi studied Indian and European Philosophy at the "Sapienza" University in Rome. Her published work is mostly about Indian philosophy of religion, of language and epistemology (see especially Duty, language and exegesis in Präbhäkara Mimāmsā, 2012; Rule-extension strategies in Ancient India, 2013; The reuse of texts in Indian Philosopby (ed.), 2014; Adaptive Reuse: Aspects of Creativity in South Asian Cultural History (ed.), 2017). She is currently principal investigator of a project on the theology of Viśiștādvaita Vedānta at the Austrian Academy of Sciences.

Malcolm Keating is Assistant Professor of Philosophy at Yale-NUS College. His research is in philosophy of language in the classical Indian and broadly Anglophone analytic traditions.

1 This article is the result of mutual discussions between its two authors. However, sections 2 and 3 should be attributed to M. Keating and sections 0,1 and 4 to E. Freschi. For Freschi's

Journal of World Philosophies 2 (Summer 2017): 42-46

Copyright (C) 2017 Elisa Freschi and Malcolm Keating.

e-ISSN: 2474-1795 • http://scholarworks.iu.edu/iupjournals/index.php/jwp• doi: 10.2979/jourworlphil.2.1.04 
part, research for this article has been financed within the WWTF project MA16-028 and the FWF project $V 400$.

2 For reasons which will become immediately apparent, we avoid the term most used in European mainstream epistemology, namely "testimony," which presupposes a speaker. (Throughout this article "European" denotes any philosophy having closely detectable European roots, independently of where its actual thinkers live.)

3 We are extremely grateful to Monika Kirloskar for agreeing to host us on Journal of World Pbilosophies and for her idea of having a few papers per issue, in order to enable an ongoing discussion on this topic.

4 All contributions to the workshop are listed and discussed here: http://elisafreschi.com/2015/06/12/linguistic-communication-as-an-instrument-ofknowledge-a-panel

5 John Locke, An Essay Concerning Human Understanding (Oxford: Oxford University Press, 1961), 58.

$6 \quad$ Knowing From Words: Western and Indian Philosopbical Analysis of Understanding and Testimony ed. Bimal Krishna Matilal and Arindam Chakrabarti (Dordrecht, Boston: Kluwer Academic, 1989).

$7 \quad$ For a short overview on the literature, see Section Two of Elisa Freschi, "There is only "Philosophy'. The case of testimony," in Constructing Sexuality, Conceptualising the Pbilosopby of Testimony, Thinking Manuscripts across Media: South Asian Perspectives. A Coffee Break Project, ed. Daniele Cuneo, Camillo Formigatti and Elisa Freschi, special issue of Kervan 21 (2017).

$8 \quad$ A.B. Keith, A History of Sanskrit Literature (Oxford: Oxford University Press, 1920), 399.

$9 \quad$ We stopped using the label "poetical" when we realized that it could be misunderstood as referring to the form of the utterance alone. For similar reasons, we avoid labels such as "metaphorical utterances" since metaphors can be successfully employed also to communicate state of affairs or to prescribe commands and do not need to be employed in order to convey affective contents.

10 Discussed in India and only a few cases in Europe.

Journal of World Philosophies 2 (Summer 2017): 42-46

Copyright (ㅇ 2017 Elisa Freschi and Malcolm Keating.

e-ISSN: 2474-1795 • http://scholarworks.iu.edu/iupjournals/index.php/jwp• doi: 10.2979/jourworlphil.2.1.04 